\title{
Experimental Study on Compressive Strength and Elastic Modulus of Ferrous Mill Tailing Concrete
}

\author{
Hong-zhen KANG * , Kai-wu JIA and Wei-hua MA \\ Department of Civil Engineering of Tangshan College, Tangshan 063000-China
}

Received 15 May 2013; Accepted 20 December 2013

\begin{abstract}
In the aim at developing and utilizing ferrous mill tailing resources to save energy, protect environment and develop sustainable society, the experimental study on ferrous mill tailing (FMT) concrete are carried out. The strength grades of concrete used in tests are C30, C35, C40, C45, C50 and C55. Based on the compressive tests, the cubic strength and prism strength of FMT concrete along with their relationship were obtained. Meanwhile, with prism compressive test, the elastic modulus of FMT concrete and its relationship with compressive standard strength also were obtained. The test results show that the ratio of prism compressive strength to cubic compressive strength for FMT concrete is about 0.8-0.9 and the FMT concrete elastic modulus increase with its strength grades.
\end{abstract}

Keywords: environmental protection, experimental study, compressive strength, elastic modulus, ferrous mill tailing

\section{Introduction}

With development of concrete technology, the quantity of consumption for natural sand is growing quickly. The shortage of natural sand resources, the growing costs of exploiting natural sand is bringing about challenge for and restricting development of the premixing concrete industry as a whole. Using ferrous mill tailing as the alternative of natural sand in concrete is an effective way to resolve this issue. Powdery mill tailing from magnetite (also called ferrous mill tailing) is the remaining material of iron ore after processed, grinded and magnetic separation. As a discharged waste, it is largely accumulated in rivers and land, polluting the surrounding areas of the natural environment. Iron ore is a rich resource in Tangshan. Some large-scale state owned companies such as Capital Steel Group is located in Qian'an of Tangshan City. Every year, discharged ferrous mill tailing by steel companies is up to about 10 million tons, occupying 2,000 acres of farmland, seriously polluting the Luan River basin. The utilization of this ferrous mill tailing is beneficial to environment protection and social sustainable development.

Nowadays, the study and utilization of ferrous mill tailing mainly focuses on concrete used in expressway engineering [1-3]. Recently years, some study on concrete properties of ferrous mill tailing concrete which is used in building structures are carried out and research findings have been obtained [4-5]. Yet, these studies are almost conducted on concrete which is mixed with part natural sand and part

\footnotetext{
*E-mail address: thkhz@sina.com

ISSN: 1791-2377 @ 2013 Kavala Institute of Technology. All rights reserved.
}

ferrous mill tailing.

In this paper, the approach to the study focus on the compressive strength and elastic modulus of FMT concrete which is mixed with fine aggregate of $100 \%$ ferrous mill tailing aiming at using ferrous mill tailing more sufficiently.

\section{Experimental materials}

The comparison test approach is employed in the study. So the fine aggregates of each mixing ratio group include two cases of natural sand and ferrous mill tailing. Testing material description, technical index and origin are listed in Table 1 .

Cement. The test-used cement is P.O42.5R Common Portland Cement, the production of Jidong Cement Company Limited. The properties of the cement are listed as Table 2.

Fly Ash. The test-used fly ash is Grade II Fly Ash produced by Tangshan Power Plant. The chemical composition of it is listed as Table 3.

Slag Powder. The fine mineral powder is selected from Blast Furnace Slag produced by Tangshan Iron and Steel Company Limited. Its chemical composition is listed in Table 4.

Ferrous Mill Tailing. The selected ferrous mill tailing is discharged by Capital Steel Group in Qian'an. Through chemical analyses, its mineral composition and chemical composition are listed in Table 5 and Table 6 respectively. 


\section{Compressive Strength program}

The goal of this program is determination of prism compressive strength and cubic compressive strength of ferrous mill tailing concrete to clarify the ratio of them and compare it with that of common concrete. Since, the concrete strength grades consist of C30, C35, C40, C45, C50 and C55. As designing the mixing ratio of each grade ferrous mill tailing concrete, admixture of flyash, slag powder and addictive should be applied to modify concrete strength, dump and divergence. According to the JGJ552011(Specification for mix proportion design of ordinary concrete)[6] and GB50119-2003(Code for utility technological of concrete admixture) [7], the mixing proportion of each grade are listed as Table 7.

Table 1. Materials Used in Tests

\begin{tabular}{c|c|c|c|c|c|c|c}
\hline Material & Cement & $\begin{array}{c}\text { Natural } \\
\text { Sand }\end{array}$ & $\begin{array}{c}\text { Ferrous Mill } \\
\text { Tailing }\end{array}$ & Gravel & Slag Powder & Fly Ash & Admixture \\
\hline $\begin{array}{c}\text { Technical } \\
\text { Index }\end{array}$ & P.O42.5 & MiddleII & MiddleII & $5-25 m m$ & S95 & II & Composite \\
Origin & Jidong Co. & Luan River & Qian'an & Fengrun & Tanglong Co. & $\begin{array}{c}\text { Douhe Power } \\
\text { Co. }\end{array}$ & Tangshan \\
\hline
\end{tabular}

Table 2. Properties of P.O42.5R

\begin{tabular}{|c|c|c|c|c|c|c|c|c|}
\hline \multirow{2}{*}{$\begin{array}{c}\text { Surface Area } \\
\text { Ratio } \\
{\left[\mathbf{m}^{2} / \mathbf{k g}\right]}\end{array}$} & \multicolumn{2}{|c|}{ Setting Time } & \multicolumn{2}{|c|}{$\begin{array}{c}\text { Compressive Strength } \\
{[\mathrm{MPa}]}\end{array}$} & \multicolumn{2}{|c|}{$\begin{array}{c}\text { Breaking Strength } \\
{[\mathrm{MPa}]}\end{array}$} & \multirow{2}{*}{$\begin{array}{c}\text { Fineness } \\
{[\%]}\end{array}$} & \multirow{2}{*}{ Stability } \\
\hline & $\begin{array}{l}\text { Initial } \\
{[\mathrm{min}]}\end{array}$ & $\begin{array}{l}\text { Final } \\
{[\mathrm{min}]}\end{array}$ & $3 d$ & $28 \mathrm{~d}$ & $3 d$ & $28 \mathrm{~d}$ & & \\
\hline 385 & 110 & 150 & 25.5 & 50.5 & 5.8 & 9.5 & 1.3 & Qualified \\
\hline
\end{tabular}

Table 3. Chemical Composition of Grade II Fly Ash

\begin{tabular}{c|c|c|c|c|c|c|c|c}
\hline Composition & Loss on Ignition & $\mathbf{S i O}_{\mathbf{2}}$ & $\mathbf{A l}_{\mathbf{2}} \mathbf{O}_{\mathbf{3}}$ & $\mathbf{F e}_{\mathbf{2}} \mathbf{O}_{\mathbf{3}}$ & $\mathbf{C a O}$ & $\mathbf{M g O}$ & $\mathbf{S O}_{\mathbf{3}}$ & $\mathbf{H}_{\mathbf{2}} \mathbf{O}$ \\
\hline Content[\%] & 6.81 & 64.50 & 19.50 & 3.40 & 9.41 & 6.82 & 0.03 & 0 \\
\hline
\end{tabular}

Table 4. Chemical Composition of Slag Powder

\begin{tabular}{c|c|c|c|c|c|c|c|c}
\hline Composition & $\mathbf{C a O}$ & $\mathbf{M g O}$ & $\mathbf{F e}_{\mathbf{2}} \mathbf{O}_{\mathbf{3}}$ & $\mathbf{A l}_{\mathbf{2}} \mathbf{O}_{\mathbf{3}}$ & $\mathbf{S i O}_{\mathbf{2}}$ & $\mathbf{K}_{\mathbf{2}} \mathbf{O}$ & $\mathbf{N a}_{\mathbf{2}} \mathbf{O}$ & $\begin{array}{c}\text { Alkaline } \\
\text { Coefficient }\end{array}$ \\
\hline Content[\%] & 35.95 & 8.71 & 1.96 & 11.52 & 37.42 & 0.51 & 0.76 & 0.91 \\
\hline
\end{tabular}

Table 5. Mineral Composition of Ferrous Mill Tailing (\%)

\begin{tabular}{c|c|c|c|c|c}
\hline Composition & Quartz & Feldspar & Pyroxene & Magnetite & Others \\
\hline Weight Ratio & 40 & 20 & 20 & 10 & 10 \\
\hline
\end{tabular}

Table 6. Chemical Composition of Ferrous Mill Tailing (\%)

\begin{tabular}{c|c|c|c|c|c|c|c|c|c}
\hline Composition & $\mathbf{S i O}_{\mathbf{2}}$ & $\mathbf{A l}_{\mathbf{2}} \mathbf{O}_{\mathbf{3}}$ & $\mathbf{T i O}_{\mathbf{2}}$ & $\mathbf{F e}_{\mathbf{2}} \mathbf{O}_{\mathbf{3}}$ & $\mathbf{K}_{\mathbf{2}} \mathbf{O}$ & $\mathbf{N a}_{\mathbf{2}} \mathbf{O}$ & $\mathbf{C a O}$ & $\mathbf{M g O}$ & $\mathbf{S O}_{\mathbf{3}}$ \\
\hline Weight Ratio & 72 & 4.4 & 0.2 & 12.9 & 1.1 & 1.1 & 2.9 & 3.8 & 0.4 \\
\hline
\end{tabular}

Table 7. Mixing Proportion $(\mathrm{kN})$

\begin{tabular}{c|c|c|c|c|c|c|c}
\hline Grade & $\begin{array}{c}\text { Ferrous Mill } \\
\text { Tailing }\end{array}$ & Cement & Fly Ash & Slag Powder & Gravel & Water & Admixture \\
\hline C30 & 884 & 220 & 75 & 105 & 997 & 169 & 7 \\
C35 & 849 & 270 & 80 & 100 & 997 & 161 & 10 \\
C40 & 817 & 320 & 80 & 90 & 999 & 159 & 12 \\
C45 & 723 & 370 & 60 & 80 & 1049 & 176 & 14 \\
C50 & 695 & 400 & 65 & 85 & 1049 & 169 & 16 \\
C55 & 684 & 420 & 70 & 90 & 1038 & 166 & 17 \\
\hline
\end{tabular}

For measuring the cubic compressive strength of FMT concrete, the specimens demission meets the specification of GB50081-2002 ( Standard for test method of mechanical properties on ordinary concrete)[8] with $150 \mathrm{~mm}$ x $150 \mathrm{~mm}$ 
x $150 \mathrm{~mm}$, as curing condition of temperature $20 \pm 2^{\circ} \mathrm{C}$ and moisture of $95 \%$ for $28 \mathrm{~d}$. Meanwhile, the prism specimens demission is $70 \mathrm{~mm} \times 70 \mathrm{~mm} \times 210 \mathrm{~mm}$ with the same curing condition. Each specimen group consists of 3 same specimens.

According to the test method of GB50081-2002, tests carried out at hydraulic universal tester. The compressive strength is calculated as:

$$
f=F / A
$$

Where, $f$ : the compressive strength $\left(\mathrm{kN} / \mathrm{mm}^{2}\right)$

$$
\begin{aligned}
& F: \text { failure loading }(\mathrm{kN}) \\
& A: \text { compressive } \operatorname{area}\left(\mathrm{mm}^{2}\right)
\end{aligned}
$$

The experimental results of cubic compressive strength and prism compressive strength are listed in Table 8 and Table 9 respectively.

Based on Data in the Table 8 and Table 9, the relationships between cubic compressive strength with concrete grade and prism compressive strength with concrete grade are curved in Figure 1. Then, the ratio of prism compressive strength to cubic compressive strength was figured out which is indicated in Figure 2.

Table 8. Cubic compressive strength

\begin{tabular}{c|c|c|c|c|c|c}
\hline $\begin{array}{c}\text { Specimen } \\
\text { Number }\end{array}$ & Grade & \multicolumn{3}{|c|}{ F (kN) } & Mean(kN) & $f($ MPa) \\
\hline A1(1-3) & C30 & 1172 & 1228 & 1192 & 1176 & 53 \\
B1(1-3) & C35 & 1300 & 1200 & 1237 & 1212 & 55 \\
C1(1-3) & C40 & 1320 & 1320 & 1323 & 1330 & 59 \\
D1(1-3) & C45 & 1400 & 1264 & 1333 & 1336 & 59 \\
E1(1-3) & C50 & 1258 & 1432 & 1351 & 1364 & 60 \\
F1(1-3) & C55 & 1700 & 1200 & 1477 & 1530 & 66 \\
\hline
\end{tabular}

Table 9. Prism compressive strength

\begin{tabular}{c|c|c|c|c|c|c}
\hline $\begin{array}{c}\text { Specimen } \\
\text { Number }\end{array}$ & Grade & \multicolumn{3}{|c|}{ F (kN) } & Mean(kN) & $f(\mathbf{M P a})$ \\
\hline A2(1-3) & C30 & 210 & 218 & 218 & 215 & 44 \\
B2(1-3) & C35 & 232 & 208 & 220 & 220 & 45 \\
C2(1-3) & C40 & 252 & 234 & 240 & 242 & 49 \\
D2(1-3) & C45 & 254 & 250 & 254 & 252 & 51 \\
E2(1-3) & C50 & 235 & 284 & 260 & 260 & 53 \\
F2(1-3) & C55 & 268 & 270 & 272 & 270 & 55 \\
\hline
\end{tabular}

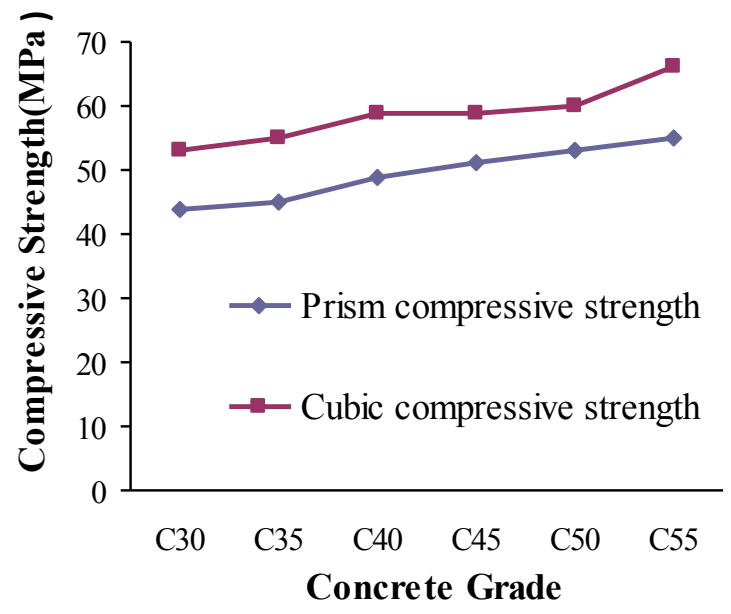

Fig.1 Relationship of strength and grade

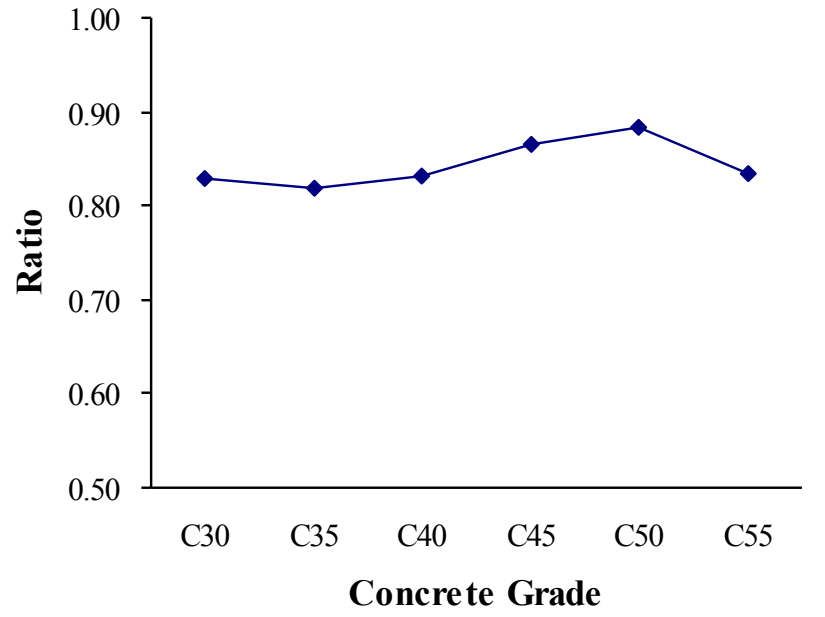

Fig. 2 Relationship of ratio and grade

As indicated in Figure 2, the ratio of prism compressive strength to cubic compressive strength of FMT concrete is 
between $0.8-0.9$, that is, $f_{\mathrm{ck}} / f_{\mathrm{cu}}=0.8-0.9$. According to GB50010-2010 (Code for design of concrete structure)[9], the ratio of prism compressive strength to cubic compressive strength of ordinary concrete is between 0.7 0.92 . Hence, the test results indicate that the ratio of prism compressive strength to cubic compressive strength of FMT concrete is in the cope of that of ordinary concrete.

\section{Elastic Modulus Program}

The elastic modulus of concrete is the key property for concrete structure design. For the use of FMT concrete in the structures, the FMT concrete elastic modulus must be determined. In this program, 21 specimens of $150 \mathrm{~mm} \times 150 \mathrm{~mm} \times 300 \mathrm{~mm}$ are fabricated and tested, with 3 specimens in each strength grade of C30, C35, C40, C45, $\mathrm{C} 50$ and C55. The concrete mix proportions are the same as Table 7. The test technology Complies with the standard of GB50081-2002. The test setup is showed in Figure 3.

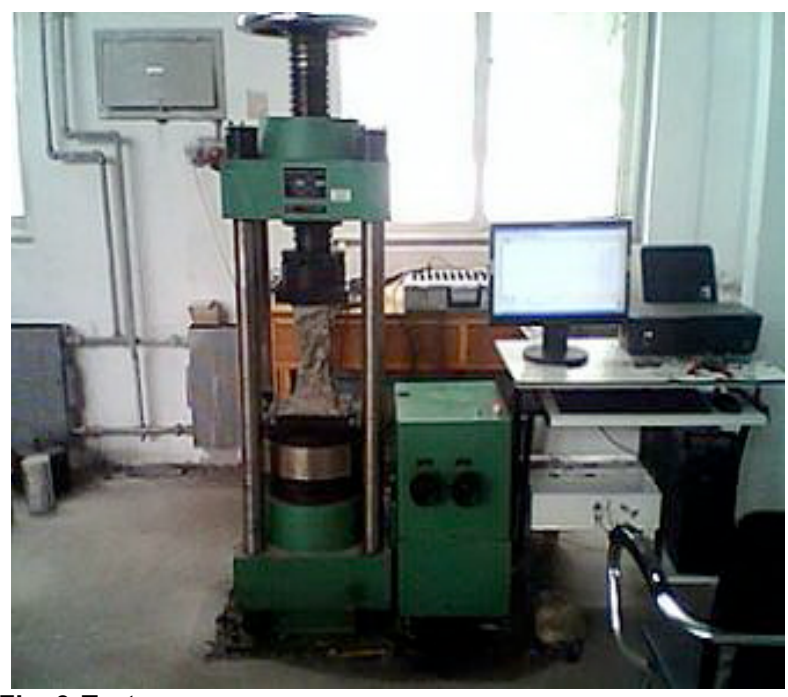

Fig. 3 Test panorama
Based on the test data, the concrete modulus $\mathrm{E}$ are calculated as:

$$
E=f / \varepsilon
$$

Where,

$f$ is the concrete stress, which is calculated as equation (1). $\varepsilon$ is the concrete strain which is measured through strain gauges pasted on specimens.

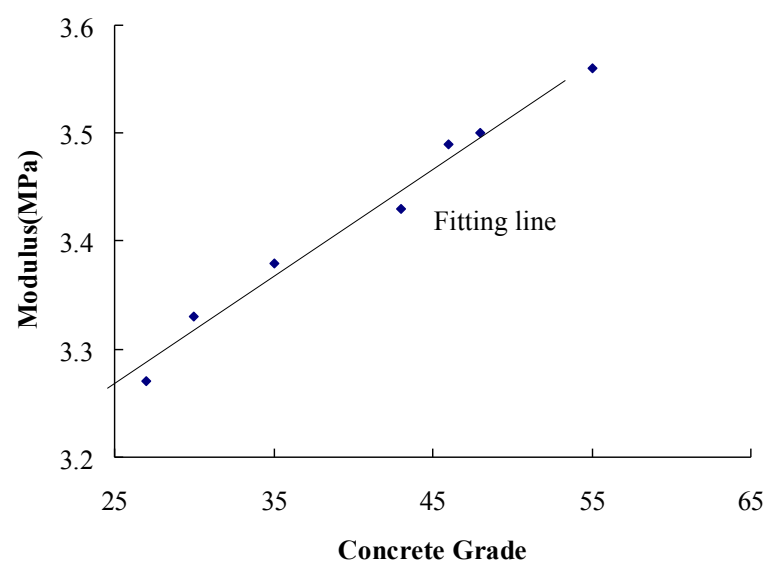

Fig. 4 The relationship of modulus with concrete grade

Table10. The elastic modulus

\begin{tabular}{c|c|c|c|c}
\hline $\begin{array}{c}\text { Specimen } \\
\text { number }\end{array}$ & $\begin{array}{c}\text { Prism strength } \\
(\mathbf{M P a})\end{array}$ & $\begin{array}{c}\text { Cubic strength } \\
(\mathbf{M P a})\end{array}$ & $\begin{array}{c}\text { Cubic standard strength } \\
(\mathbf{M P a})\end{array}$ & $\begin{array}{c}\text { Modulus } \\
(\mathbf{M P a})\end{array}$ \\
\hline WKS1-4 & 26 & 34 & 27 & 3.27 \\
WKS1-5 & 29 & 38 & 30 & 3.33 \\
WKS1-6 & 33 & 43 & 35 & 3.38 \\
WKS2-4 & 41 & 54 & 43 & 3.43 \\
WKS2-5 & 43 & 57 & 46 & 3.49 \\
WKS2-6 & 44 & 58 & 48 & 3.50 \\
WKS3-4 & 50 & 66 & 55 & 3.56 \\
\hline
\end{tabular}

Table11. FMT concrete elastic modulus $\left(10^{4} \mathrm{~N} / \mathrm{mm}^{2}\right)$

\begin{tabular}{c|l|l|l|l|l|l|l}
\hline Strength grade & C25 & C30 & C35 & C40 & C45 & C50 & C55 \\
\hline $\boldsymbol{E}$ & 3.25 & 3.30 & 3.35 & 3.40 & 3.45 & 3.50 & 3.55 \\
\hline
\end{tabular}

The test results are listed in Table 10. 
Based on the data listed in Table 10, the vary curve of modulus with concrete grade is plotted in Figure 4, in which the straight line is fitting straight-line.

As indicated in Figure 4, it can be include that the modulus of FMT concrete increases with its cubic standard strength from $3.27 \mathrm{MPa}$ with strength of $27 \mathrm{MPa}$ to $3.56 \mathrm{MPa}$ with strength of $55 \mathrm{MPa}$. In figure 4 , according to the curve vary, a straight fitting line was plotted. With this fitting line, the FMT concrete modulus with each strength grade can be listed in Table 11.

\section{Stress-strain relationship of FMT concrete}

For measuring the stress-strain relationship of FMT concrete, 30 specimens with dimension of $70 \mathrm{~mm} \times 70 \mathrm{~mm} \times 210 \mathrm{~mm}$ are fabricated and tested, each group includes 3specimens and the concrete grades are C20, C25, $\mathrm{C} 30, \mathrm{C} 35, \mathrm{C} 40, \mathrm{C} 45, \mathrm{C} 50$ and $\mathrm{C} 55$. The curing condition is the same as the elastic modulus specimens.

The stress-strain relationship tests are carried out at LVDT loading instrument, which is indicated as Figure 5.

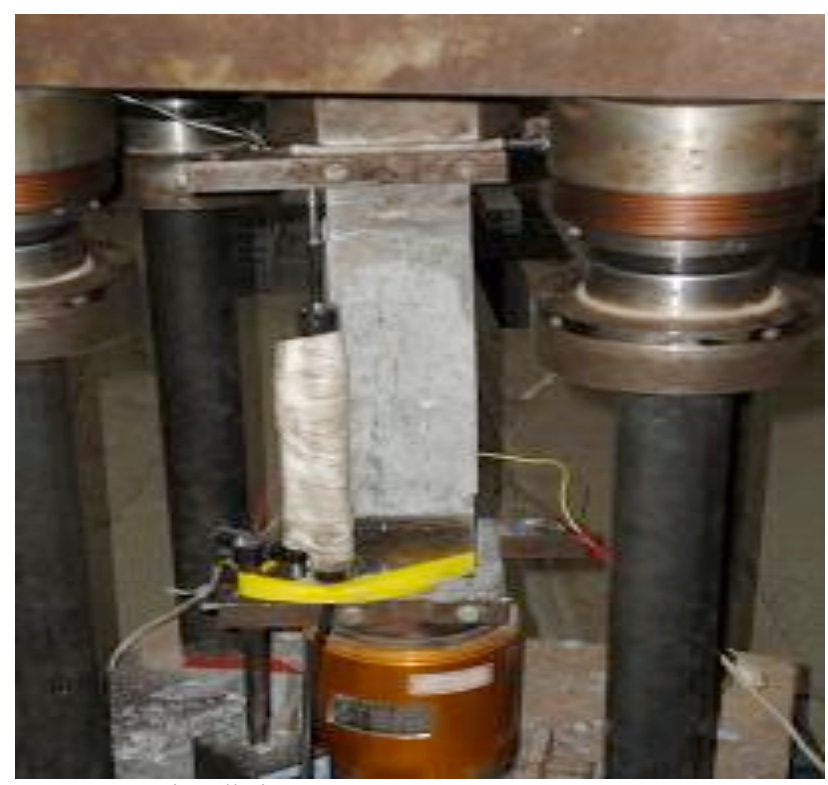

Fig. 5 LVDT installation

The test data are listed in Table 12.

Table 12 Stress-strain test data

\begin{tabular}{c|c|c|c|c|c|c}
\hline Number & $\begin{array}{c}\text { Peak } \\
\text { Stress }\end{array}$ & $\begin{array}{c}\text { Peak } \\
\text { Strain }\end{array}$ & $\begin{array}{c}\text { Peak } \\
\text { Stress }\end{array}$ & $\begin{array}{c}\text { Peak } \\
\text { Strain }\end{array}$ & $\begin{array}{c}\text { Peak } \\
\text { Stress }\end{array}$ & $\begin{array}{c}\text { Peak } \\
\text { Strain }\end{array}$ \\
\hline $\mathrm{A}(4-6)$ & 173 & 1518 & 137 & 1577 & 150 & 1568 \\
$\mathrm{~B}(4-6)$ & 193 & 1306 & 184 & 1566 & 197 & 1417 \\
$\mathrm{C}(4-6)$ & 214 & 1416 & 190 & 1233 & 193 & 1300 \\
$\mathrm{D}(4-6)$ & 285 & 1753 & 239 & 1516 & 241 & 1543 \\
$\mathrm{E}(4-6)$ & 231 & 1301 & 262 & 1400 & 230 & 1322 \\
$\mathrm{~F}(4-6)$ & 304 & 1722 & 298 & 1628 & 261 & 1510 \\
$\mathrm{G}(4-6)$ & 334 & 1796 & 270 & 1353 & 312 & 1482 \\
$\mathrm{H}(4-6)$ & 298 & 1706 & 317 & 1773 & 307 & 1896 \\
\hline
\end{tabular}

With the test data, some of the stress-strain relationship curves of FMT concrete with various strength grades are illustrated in Figure 6.

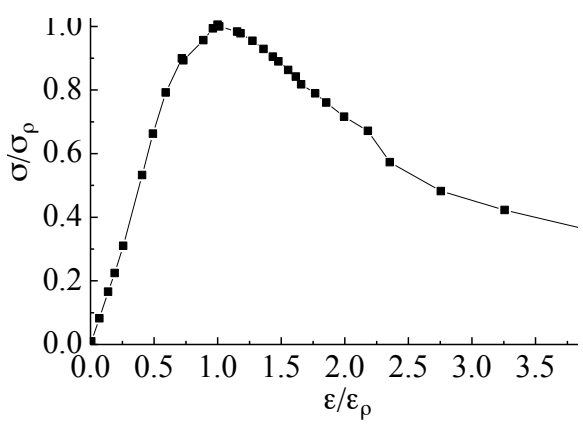

(a) A-4 Stress-strain curves

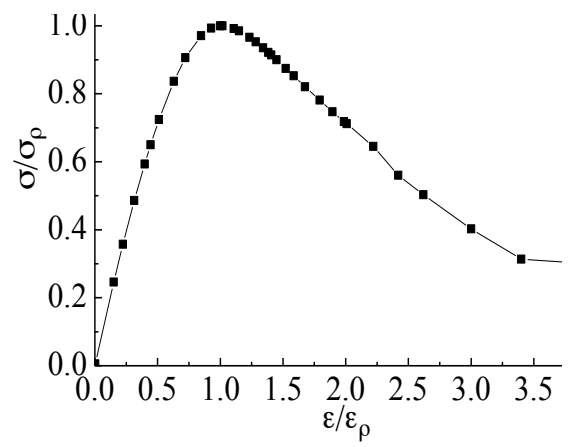

(b) I-4 Stress-strain curves

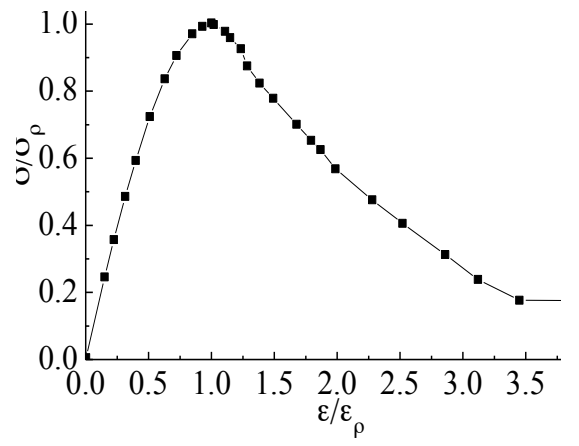

(c) J-4 Stress-strain curves

Fig. 6 Some specimen stress-strain relationship curves

Figure 7 illustrates the stress-stain relationship curves of the specimens of A, C, D and $\mathrm{H}$ group which indicates that the peak strains with various strength grades vary little while the peak stresses increase with increasing grades, and the descent stages become steep with increasing strength grades.

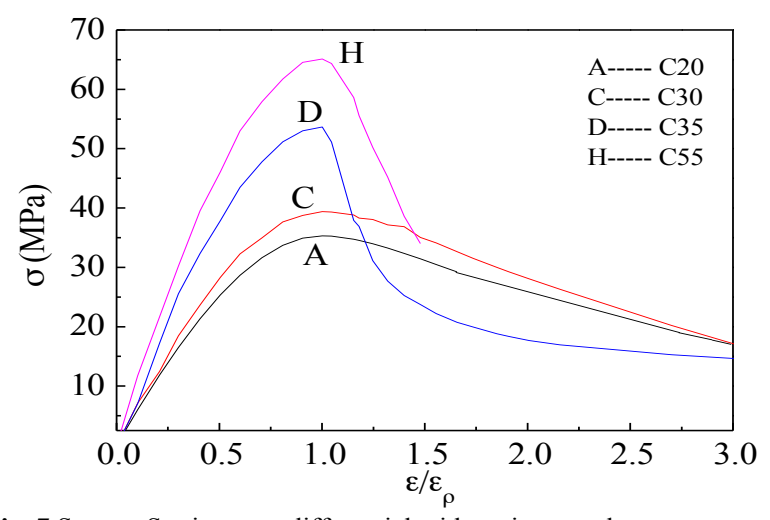

Fig. 7 Stress - Strain curve differential with various grades 


\section{Conclusions}

Through experiments and analyses, the following conclusions are proposed:

1. The prism compressive strength of FMT concrete in this test is 0.8-0.9 times of its cubic strength.

2. The modulus of FMT concrete increases with its standard compressive strength.

3. A straight fitting line of relationship between modulus and standard compressive strength of FMT concrete was figured out according to the test results.
4. The stress-strain relationships of various strength grades of FMT concrete are obtained.

\section{Acknowledgements}

This work was sponsored by the National Natural Science Foundation of China (51378331), the Science and Technology Research Program of Tangshan, China (12130209A-4) and the Construction Technology Innovation Program of Hebei Province of China (2011-230).

1. Qing Yang, Bao Fen Pan and Yun Ming He, "Study of ferrous mill tailing use in highway subgrade", East China Highway, 178, 2009, pp 77-80. (in Chinese)

2. WEI Lian-yu, LI Hai-feng, LIU Yong-chun, "Pavement Performance of Mine Tailing Sand Base", Transport Standardization, 218,2010, pp135-138. (in Chinese)

3. PAN Bao-feng, WANG Yan, ZHANG Tie-zhi, "Research on freezing-thawing characteristics of inorganic binders stabilized iron tailings", Low Temperature Architecture Technology, 139, 2010, pp 8-10. (in Chinese)

4. CAI Ji-wei, WU Ji-xu, LU Zhen-hang," Effects of powdery mill tailings from magnetite on workability and strength of concretes", Key Engineering Materials, 477, 2011, pp. 233-238.

5. CHAI Hong-jun, SONG Yu-zeng, WANG Xing-yuan, "Characteristic of iron ore tail and the affects on concrete mixing content”, Construction Quality, 28, 2010, pp. 71-75.(in Chinese)

6. JGJ55-2011. "Specification for Mix Proportion Design of Ordinary Concrete", China Building Industry Press, Beijing, 2011. (in Chinese)

7. GB50119-2003. "Code for Utility Technical of Concrete Admixture Concrete", China Building Industry Press, Beijing, 2003. (in Chinese)

8. GB50081-2002. "Standard for test method of mechanical properties on ordinary concrete", China Building Industry Press, Beijing, 2003. (in Chinese)

9. GB50010-2010. "Code for design of concrete structure", China Building Industry Press, Beijing, 2010. (in Chinese)

10. E.Kaplani," Desigh and Performance considerations in stand-alone PV powered telecommunication systems", Journal of Engineering Science And Technology Review 5(1),2012, pp.1-6.

11. Sh. Mirseidova, A. Inoue, L. Atymtayeva,"Evaluaton of Fair Market Price of Resources In Oil And Gas Industry Using Fuzzy Sets And Logics",Computer Modelling and New Technologies,16(1),2012,pp.30-34. 